Jpn. J. Med. Sci. Biol., 43, 29 - 36, 1990.

\title{
PREVALENCE OF HEPATITIS C VIRUS AN'TIBODY AMONG HEALTHY BLOOD DONORS AND NON-A, NON-B HEPATITIS PATIEN'TS IN THAILAND
}

Sumalee BOONMAR*, Boonsong POJANAGAROON1, Yushiro WATANABE, Yukie TANAKA, Izumu SAITO and Tatsuo MIYAMURA

Department of Enteroviruses, National Institute of Health, Kamiosaki, Shinagawa-ku, Tokyo 141, and 1Virus Research Institute, Department of Medical Sciences, Ministry of Public Health, 88/7 Gp4 Soi Bamrasnaradura Hospital, Nonthaburi, Thailand

(Received March 5, 1990. Accepted May 17, 1990)

SUMMARY: With the antigen expressed in yeast from a cDNA clone encoding a non-structural region of newly discovered hepatitic $\mathrm{C}$ virus (HCV) genome, the prevalence of $\mathrm{HCV}$ antibody in people in Thailand was investigated. Antibody was detected in $2.6 \%$ of healthy blood donors and in $2.8 \%$ of healthy pregnant women. These prevalence rates were higher than those reported previously from Japan, USA and European countries. Among community-acquired, sporadic cases of acute and chronic non-A, non-B hepatitis, however, only $5.7 \%$ and $15.4 \%$ were shown to possess the antibody, respectively. Among hepatocellular carcinoma patients who were negative for hepatitis B surface antigen in the sera, $11.1 \%$ had antibody to HCV. These seroepidemiological data suggest that HCV plays an important role as an etiological agent in Thailand; however, other agents must also be involved in etiologic agents of viral hepatitis and chronic liver disease.

渡辺勇四郎·田中幸江·斎藤 泉・宮村達男 (国立予防衛生研究所腸内ウイルス部)

*Permanent address: Virus Research Institute, Department of Medical Sciences, Ministry of Public Health, 88/7 Gp4 Soi Bamrasnaradura Hospital, Nonthaburi, Thailand.

Requests for reprints should be addressed to Dr. T. Miyamura, Department of Enteroviruses, National Institute of Health, Kamiosaki, Shinagawa-ku, Tokyo 141, Japan. 


\section{INTRODUCTION}

More than $90 \%$ of transfusion-associated hepatitis cases in the world are caused neither by hepatitis A nor hepatitis B viruses (1-4). After a long and extensive search for the etiological agent(s) for non-A, non-B hepatitis (NANBH), a cDNA clone expressing a protein which specifically reacts with sera from chronically infected NANBH patients was obtained. The cDNA was later identified to be derived from the $10 \mathrm{~kb}$ genome of an RNA virus now termed hepatitis $\mathrm{C}$ virus (HCV) (5). Serological assays to detect antibody to a nonstructural gene product of the virus (anti-HCV) performed in the USA, Japan and Italy have shown that $\mathrm{HCV}$ is a major causative agent for transfusionassociated NANBH (6-9). In these countries, more than $50 \%$ of NANBH patients with no history of blood transfusion have been shown to have anti-HCV. This suggests that HCV is also associated with cases of sporadic or communityacquired NANBH.

We have conducted a sero-survey to examine the prevalence of anti-HCV in a population where multiple agents play an etiological role in development of hepatitis. In Thailand, viral hepatitis is one of the major public health problems (10). The annual summary of the Ministry of Public Health in 1985 reported the annual incidence of viral hepatitis to be 34.6 cases per 100,000 population (10). Among these cases, $37.9 \%$ were caused by hepatitis A and $43.3 \%$ by hepatitis $B$. The rest were designated as NANBH. A recently discovered hepatitis $\mathrm{E}$ virus is considered to play an important role as a causative agent for NANBH in Asian countries including Thailand (11). We have examined the prevalence of anti$\mathrm{HCV}$ among Thai people to know the etiological significance of HCV in sporadic, community-acquired hepatitis cases in an area where multiple viral agents are associated in the development of hepatitis.

\section{MATERIALS AND ME'THODS}

Serum collection: Five groups of sera were collected; Group 1 included sera from 390 healthy blood donors. Blood in this series were collected, examined and used for transfusion at Thai Red Cross Institute in August in 1989. They were of course all negative for hepatitis B virus surface antigen ( $\mathrm{HBsAg}$ ) and their alanine aminotransferase (ALT) levels were below 35 units. Group 2 consisted of sera from 212 healthy pregnant women visiting the Thai Navy Hospital during 
October to December in 1988. Group 3 sera were from 35 acute cases of NANBH. These sera were collected during May to October in 1988 at Vajira Hospital and Chantabur Hospital in Bangkok. The diagnosis of NANBH was based on clinical features and the exclusion of HAV and HBV infections by the absence of specific serum markers. Group 4 sera were from 13 chronic NANBH patients at National Cancer Institute, Bangkok. All sera were examined to exclude infections of HAV, HBV and cytomegalovirus. None of these patients had previously received blood transfusions. Group 5 included sera from 47 randomly selected patients with hepatocellular carcinoma who were hospitalized at National Cancer Institute.

Serological tests: HBsAg was tested by the reverse passive hemagglutination test, $\mathrm{HBsAb}$ by the passive hemagglutination test and $\mathrm{HBeAg}$ by the reverse passive hemagglutination test. Anti-HAV was tested by the enzyme linked immunosorbent assay (ELISA). Anti-HCV was assayed by the ELISA technique with Chiron kits provided by Ortho-Diagnostics of Japan. Briefly, a part of non-structural region (NS3/NS4) of HCV cDNA was expressed in yeast in the form of a fused polypeptide with human superoxide dismutase (C100-3) (6). After extensive purification, the antigen was fixed onto microtiter plate wells to capture circulating anti-HCV in serum specimens. Specific antigen-antibody complexes were bound to murine anti-human IgG monoclonal antibody conjugated with horseradish peroxidase. After addition of the o-phenylenediamine-dihydrochrolide substrate, the bound conjugates were oxidized and their optical density (OD) measured with a microwell reader. Sera with OD values over the cut-off values determined according to the manufacturer's instruction were considered positive.

\section{RESULTS AND DISCUSSION}

To determine the prevalence of anti-HCV among healthy people in Thailand, we assayed 390 healthy blood donor serum samples. These sera were from blood used for transfusion in the Bangkok and all negative for HBs antigen. Their alanine aminotransferase levels were below $35 \mathrm{Karmen}$ units. As shown in Table I, 10 of 390 donors had anti-HCV. The male and female ratio reflected the actual blood donation during the period of the study and no sex difference in anti$\mathrm{HCV}$ positivity was found.

We expanded the study to analyze 212 samples from healthy pregnant women collected in a hospital in Bangkok area. Their ages ranged from 18 to 35 with an average of 21.5 years. Six of the 212 pregnant women were positive for anti-HCV (Table II). The prevalence of anti-HCV was similar or even lower in 
Table I. Anti-HCV among Thai blood donors

\begin{tabular}{lrlc}
\hline $\begin{array}{l}\text { Range } \\
\text { of } \\
\text { age }\end{array}$ & Number & $\begin{array}{l}\text { Sex } \\
\text { M / F }\end{array}$ & Anti-HCV positive (\%) \\
\hline $10-20$ & 153 & $147 / 6$ & $4(2.6)$ \\
$21-30$ & 101 & $73 / 28$ & $4(4.0)$ \\
$31-40$ & 83 & $56 / 27$ & $1(1.2)$ \\
$41-50$ & 37 & $31 / 6$ & $1(2.7)$ \\
$51-60$ & 13 & $12 / 1$ & - \\
$61-70$ & 3 & $3 / 0$ & - \\
\hline Total & 390 & $322 / 68$ & $10(2.6)$ \\
\hline
\end{tabular}

Table II. Anti-HCV among healthy pregnant women in Thailand

\begin{tabular}{lcc}
\hline HBV marker & Number tested & Anti-HCV positive (\%) \\
\hline HBsAg(+), HBeAg(+) & 72 & $3(4.2)$ \\
HBsAg(+), HBeAb(+) & 72 & $2(2.8)$ \\
HBsAg(-) & 68 & $1(1.5)$ \\
\hline Total & 212 & $6(2.8)$ \\
\hline
\end{tabular}

HBsAg-negative pregnant women than in HBsAg carrier women. The overall antibody prevalence was similar to that of healthy donors.

The prevalence of anti-HCV among these two healthy groups suggested that HCV carrier rate is about $2.6-2.8 \%$. This is higher than the values reported previously from Japan, USA and European countries ranging 0.5-1.5\% (6,8,9,1215 ) by the use of the same assay system described here. In Thailand, $3.1 \%$ of the population under the age of 30 were positive, whereas only $0.45 \%$ of the normal population of those ages in Japan had HCV antibody (K. Nishioka, personal communication). The observed higher prevalence of HCV antibody is not 
Table III. Anti-HCV in sera from acute and chronic non-A, non-B hepatitis patients in Thailand

\begin{tabular}{lcl} 
& Number tested & Anti-HCV positive (\%) \\
\cline { 2 - 3 } Acute NANBH & 35 & $2(5.7)$ \\
Chronic NANBH & 13 & $2(15.4)$ \\
\hline
\end{tabular}

Table IV. Anti-HCV in 47 hepatocellular carcinoma patients

\begin{tabular}{|c|c|c|c|}
\hline \multicolumn{2}{|c|}{ HBV marker } & \multirow{2}{*}{$\begin{array}{c}\text { Number tested } \\
10\end{array}$} & \multirow{2}{*}{$\frac{\text { Anti-HCV positive (\%) }}{1(10.0)}$} \\
\hline A. & HBsAg(-), HBsAb(-) & & \\
\hline B. & $\operatorname{HBsAg}(-), \operatorname{HBsAb}(+)$ & 8 & $1(12.5)$ \\
\hline C. & $\mathrm{HBsAg}(+)$ & 29 & $1(3.4)$ \\
\hline
\end{tabular}

consistent with the low incidence of post-transfusion NANBH in Thailand, which was reported to be $0.5 \%$ (16). The reasons for this are not known, but the lack of precise nationwide surveillance for NANBH may be responsible for the underestimated incidence.

We examined HCV antibody among patients clinically diagnosed as NANBH. None of these patients had a previous history of blood transfusion. Two of $35(5.7 \%)$ sera collected at acute phases were positive for HCV antibody, while two of 13 patients $(15.4 \%)$ in chronic phases had anti-HCV (Table III). Although the numbers were small, anti-HCV positivities among both acute and chronic cases of clinically diagnosed community-acquired (sporadic) NANBH were lower than those observed previously in Japan and other countries. In Thailand, HCV plays a significant role as an etiological agent for NANBH, but some other agent(s) may also be involved for the development of the disease.

Chronic NANBH may result in the development of liver cirrhosis and hepatocellular carcinoma (HCC). In Japan, over $70 \%$ of non-B HCC patients have anti-HCV suggesting that HCV infection may be related to the development of HCC (Saito et al., manuscript submitted). We investigated the prevalence of anti- 
HCV patients in Thai. Sera obtained from $47 \mathrm{HCC}$ patients hospitalized in National Cancer Institute in August, 1989 were divided into three groups according to their serum markers of HBV. Group A was composed of 10 patients who had no serum markers for HBV infection, group B was of eight patients being positive only for $\mathrm{HBs}$ antibody and negative for $\mathrm{HBsAg}$, and group $\mathrm{C}$ contained 29 $\mathrm{HBsAg}$ carriers. Previous reports indicated that the HBsAg carrier rates in HCC patients in Thailand were 30-75\% (17-19). Anti-HCV was detected in one patient from each of these groups (Table IV). None of these anti-HCV-positive patients received blood transfusion previously. The prevalence of anti-HCV among non-B $\mathrm{HCC}$ (groups A and B; 11.1\%) in Thailand is thus significantly lower than that observed in Japan. This is suggestive also of the presence of other agent(s) in the development of HCC in Thailand.

We are currently cloning a part of cDNA of the HCV genome from some of the healthy blood donors in Thailand who were shown to have anti-HCV in this study. The cDNA is from the NS3 region close to the region where the antigen used for the assay is coded. More detailed seroepidemiological studies and further molecular analysis of the Thai HCV isolate will elucidate the significance of HCV infection in regions where hepatitis $\mathrm{A}, \mathrm{B}$, and $\mathrm{E}$ have not been controlled.

\section{ACKNOWLEDGEMEN'TS}

We thank Dr. Dennis W. Trent for reviewing the manuscript. We are indebted to Dr. Boonluan Phanthumachinda, the Deputy Director of Department of Medical Science, Dr. Chunrudee Chaivasu, the Director of Virus Research Institute, and Dr. Koomi Kanai, the Japanese Expert at National Institute of Health of Thailand, for their enthusiastic supports of this study. We also thank Dr. Petcharin Srivatanakul at National Cancer Institute and Dr. Srivilai Tanprasert at Red Cross Institute for their generous gift of blood samples, Mr. Napa Pathomyothin and Mr. Somdej Charoenphon for their help in collecting sera, and Ms. Tomoko Mizoguchi for secretarial assistance. S. B. is a visiting fellow supported by the Research Promotion Project of National Institute of Health of Thailand and Japan International Cooperation Agency. 


\section{REFERENCES}

1. Feinstone, S. M., Kapikian, A. Z., Purcell, R. H., Alter, H. J. and Holland, P. V. (1975): Transfusion-associated hepatitis not due to viral hepatitis type A or B. New Engl. J. Med., 292, 767-770.

2. Knodell, R. G., Conrad, M. E. and Dienstag, J. L. (1975): Liver physiology and disease. Etiological spectrum of post-transfusion hepatitis. Gastroenterology, 69, 1278-1285.

3. Alter, H. J., Purcell, R. H., Holland, P. V., Feinstone, S. M., Morrow, A. G. and Moritsugu, Y. (1975): Clinical and serological analysis of transfusionassociated hepatitis. Lancet, ii, 838-841.

4. Tateda, A., Kikuchi, K., Numazaki, Y., Shirachi, R. and Ishida, N. (1979): Non-B hepatitis in Japanese recipients of blood transfusions: Clinical and serologic studies after the introduction of laboratory screening of donor blood for hepatitis B surface antigen. J. Infect. Dis., 139, 511-518.

5. Choo, Q.-L., Kuo, G., Weiner, A. J., Overby, L. R., Bradley, D. W. and Houghton, M. (1989): Isolation of a cDNA clone derived from a blood-borne non-A, non-B viral hepatitis genome. Science, 244, 359-362.

6. Kuo, G., Choo, Q.-L., Alter, H. J., Gitnick, G. L., Redeker, A. G., Purcell, R. H., Miyamura, T., Dienstag, J. L., Alter, M. J., Stevens, C. E., Tegtmeier, G. E., Bonino, F., Colombo, M., Lee, W.-S., Kuo, C., Berger, K., Shuster, J. R., Overby, L. R., Bradley, D. W. and Houghton, M. (1989): An assay for circulating antibodies to a major etiologic virus of human non-A, non-B hepatitits. Science, 244, 362-364.

7. Alter, H. J., Purcell, R. H., Shih, J. W., Melpolder, J. C., Choo, Q.-L. and Kuo, G. (1989): Detection of antibody to hepatitis $C$ virus in prospectively followed transfusion recipients with acute and chronic non-A, non-B hepatitits. New Engl. J. Med., 321, 1494-1500.

8. Miyamura, T., Saito, I., Katayama, T., Kikuchi, S., Tateda, A., Choo, Q.-L., Houghton, M. and Kuo, G. (1989): Detection of antibody against antigen expressed by molecularly cloned hepatitis $\mathrm{C}$ virus cDNA: Application to diagnosis and blood screening for posttransfusion hepatitis. Proc. Natl. Acad. Sci. USA, 87, 983-987.

9. Katayama, T., Kikuchi, S., Miyamura, T., Saito, I., Tanaka, Y., Choo, Q.-L., Houghton, M. and Kuo, G. (1990): Blood screening for non-A, non-B hepatitis by hepatitis $\mathrm{C}$ virus antibody assay. Transfusion, in press.

10. Annual Report of Ministry of Public Health, Thailand (1985)

11. Ramalingaswami, V. and Purcell, R. H. (1988): Waterborne non-A, non-B hepatitis. Lancet, i, 571-573.

12. Esteban, J. I., Esteban, R., Viladomiu, L., Lopez-Talavera, J. C., Gonzalez, A., Hernandez, J. M., Roget, M., Vargas, V., Gnesca, J., Buti, M., Guardia, J., Houghton, M., Choo, Q.-L. and Kuo, G. (1989): Hepatitis C virus antibodies among risk groups in Spain. Lancet, ii, 294-297. 
13. Van der Poel, C. L., Reesink, H. W., Lelie, P. N., Leentvaar-Kuypers, A., Choo, Q.-L., Kuo, G. and Houghton, M. (1989): Anti-hepatitis C antibodies and non-A, non-B post-transfusion hepatitis in the Netherlands. Lancet, ii, 297-298.

14. Kuhnl, P., Seidl, S., Stangel, W., Beyer, J., Sibrowski, W. and Flik, J. (1989): Antibody to hepatitis C virus in German blood donors. Lancet, ii, 324.

15. Roggendorf, M., Deinhardt, F., Rasshofer, R., Eberle, J., Hopf, U., Moller, B., Zachoval, R., Pape, G., Schramm, W. and Rommel, F. (1989): Antibodies to hepatitis $\mathrm{C}$ virus. Lancet, ii, 324-325.

16. Punyaguptu, S. (1987): Hepatitis infections disease after blood transfusion, role of virus non-A, non-B. J. Infect. Dis. Antimicrob. Agents, 4, 86-91 (in Thai).

17. Phornphutkul, K. and Peerkorme, S. (1982): The frequency of hepatitis B surface antigen in hepatocellular carcinoma patients in Northern Thailand. Chiang Mai Medical Bulletin, 21, 345-350.

18. Pongpicat, D., Suvatte, V. and Assateerawatts, A. (1983): Hepatitis B surface antigen and alpha-foetoprotein in paediatric hepatocellular carcinoma and hepatoblastoma in Thailand. Asian Pacific J. Allergy Immun., 1, 104-106.

19. Srivatunakul, P., Burke, D. S., Thanasombutt, S. and Tan-Ngarmtrong, D. (1983): Serum markers of hepatitis A and B virus infection in Thai patients with primary hepatocellular carcinoma. Thai Cancer J., 9, 113-117. 